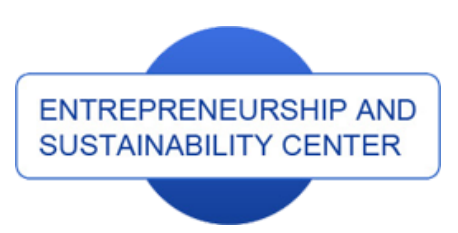

Publisher

http://jssidoi.org/esc/home enterprise

europe

network

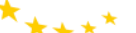

Business Support on Your Doorstep
Scopus

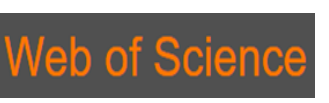

\title{
EVALUATION OF THE EFFICIENCY OF INDUSTRIAL MANAGEMENT IN HIGH-TECHNOLOGY INDUSTRIES*
}

\author{
Aleksandr M. Batkovskiy ${ }^{1}$, Natalya S. Efimova ${ }^{2}$, Vyacheslav D. Kalachanov ${ }^{3}$, Elena G. Semenova ${ }^{4}$, \\ Alena V. Fomina ${ }^{5}$, Victor M. Balashov ${ }^{6}$ \\ 1,5 JSC “Central Research Institute of Economy, Management and Information Systems "Electronics" \\ 12 Kosmonavta Volkova Str., Moscow, 127299, Russian Federation \\ ${ }^{2,3}$ Moscow Aviation Institute (National research university) \\ 4 Volokolamskoe shosse Str., Moscow, 125993, Russian Federation \\ ${ }^{4}$ Saint-Petersburg State University of Aerospace Instrumentation \\ 67 Bolshaya Morskaia Str., Saint-Petersburg, 190000, Russian Federation \\ ${ }^{6}$ JSC «Scientific and Production Enterpise "Radar MMS”» \\ 37A Novoselkovskaya Str., Saint-Petersburg, 197375, Russian Federation \\ E-mails.1ㅁatk0vskiy_a@instel.ru ; ${ }^{2}$ efimova.ns@mail.ru ; ${ }^{3}$ kaf5o6@mail.ru ; ${ }^{4}$ egsemenova.@mail.ru ; \\ ${ }^{5}$ fomina_a@instel.ru ; ${ }^{6}$ balashov_vm@radar.mms.com
}

Received 15 March 2018; accepted 10 October 2018; published 30 December 2018

\begin{abstract}
The realization of structural changes in high-technology industries requires an evaluation of the effectiveness of taken decisions. For this purpose, the paper considers the technical and economic feasibility of developing a system of indicators in industrial management, which will allow increasing the competitiveness of products. A set of indicators was developed, based on the formalization of the main characteristics and interrelation of the organizational structure, and an integral estimation of the organizational potential of high-technology enterprises was proposed. The application of such a technique in practice will give a preliminary conclusion about the nature of structural transformations. In developing the methodology, a criterion is proposed for estimating the competitiveness of a high-technology enterprise, which is based on the ratio of its potentials to actual risks. Structurally functional identification of the potentials of the processes of functional systems made it possible to reveal the features of the application of analytical models for determining the accumulated potentials in the production system. This gives the possibility for segmentation of the enterprise's competitiveness and determination of areas with different efficiency of resource consumption.
\end{abstract}

Keywords: industrial enterprises; high-technology products; produc-tion processes; competitiveness; high-technology industries

\footnotetext{
* The study was supported by the Russian Foundation for Basic Research (RFBR), project No. 16-06-00028
} 
The International Journal
ENTREPRENEURSHIP AND SUSTAINABILITY ISSUES

ISSN 2345-0282 (online) http://jssidoi.org/jesi/

2018 Volume 6 Number 2 (December)

http://doi.org/10.9770/jesi.2018.6.2(8)

Reference to this paper should be made as follows: Batkovskiy, A.M.; Efimova, N.S.; Kalachanov, V.D.; Semenova, E.G.; Fomina, A.V.; Balashov, V.M. 2018. Evaluation of the efficiency of industrial management in high-technology industries. 2018. Entrepreneurship and Sustainability Issues 6(2): 577-590. http://doi.org/10.9770/jesi.2018.6.2(8)

JEL Classifications: C15, D21, D24

\section{Introduction}

The creation of knowledge-intensive products is one of the main components of the effective development and operation of most industrial enterprises. Their task is to maximize the effectiveness of the management system. In this regard, the choice of indicators characterizing the final results of the work of these enterprises is of great importance. Changing the configuration of the organizational structure of high-technology enterprises is associated with the need to introduce organizational and economic methods and procedures aimed at a standard unified information environment that ensures achieving some technological, economic (including operational ones) characteristics and indicators of knowledge-intensive products. One of the most important trends in improving industrial management in knowledge-intensive industries is the improvement of the quality of industrial Indicators and the search for new ones.

When calculating the generalized indicators of production and sales volumes of high-technology products, the authors propose the following indicators: volume of high-technology products; work-in-process inventory; ratio of high-technology products; ratio of high-technology products to work-in-process inventory; volume of hightechnology products sold. The introduction of such industrial and financial-economic indicators will make it possible to determine the necessity of carrying out structural transformations in high-technology industries in order to optimize enterprises and reduce excess production capacity, and the advisability of organizational decisions on structural changes in the production system at enterprises. All this predetermined the development of a methodological tool for the effective management of production in high-technology industries.

\section{Review of literature}

In order to develop some management solutions for effective mechanisms for knowledge-intensive enterprises, it is necessary to use a single conceptual construct and some methodological tools to evaluate their competitiveness. Many of its definitions testify to the complexity of this economic category and the possibility of a diverse study.

It is advisable to analyze the effectiveness of organizational management structures of enterprises on the basis of the following approaches: financial and economic; expert-methodical and resource-potential ones. Various approaches to the effective management of production processes in the creation of high-technology products are discussed in scientific papers by Panahifar et al. (2014), Li et al. (2017), Chen et al. (2016), etc. Methodological tools for assessing the competitiveness of the industrial sectors are considered in the scientific papers by Knutstad and Ravn (2014), Berger (2014), Huys et al. (2013), De Sousa Damiani (2016), Hong et al. (2016), Ingvaldsen (2015). The issues of enterprise evaluation of efficiency are discussed in scientific works by Pokrajac et al. (2016), Lyu et al. (2016), Batkovskiy et al. (2016), Lee (2011), Manturov and Efimova (2012), Rolfsen and Langeland (2012), Narkuniené and Ulbinaitè (2018).

When analyzing the effective management of organizational structures, the indicators in Table 1 are used. 
Table 1. Various indicators used in the analysis of effective management of organizational structures

\begin{tabular}{|c|c|}
\hline $\begin{array}{c}\text { Item } \\
\text { number }\end{array}$ & Indicators \\
\hline 1. & Valuation indicators based on the analysis of financial and economic performance \\
\hline 2. & $\begin{array}{l}\text { The complex index calculated by the ratio of profit (as a rule) to the indicators of financial and economic activity of } \\
\text { the enterprise }\end{array}$ \\
\hline 3. & Indicators used in ranking their sample multitude \\
\hline 4. & $\begin{array}{l}\text { The complex indicator }-E_{s} / E_{p} \text {, combining the indicator of the economy of the management system } E_{s} \text { (the ratio of } \\
\text { management costs to the cost of fixed assets and working capital) and the index of effectiveness of production } E_{p} \text { (the } \\
\text { ratio of productivity to the number of employees) }\end{array}$ \\
\hline 5 . & $\begin{array}{l}\text { Indicators used in the expert method of evaluation (goals and functions of management, characteristics of its process, } \\
\text { methods, etc.) }\end{array}$ \\
\hline 6. & Indicators characterizing the target $(P / S)$ and resource $(P / Z)$ efficiency: $E=\phi(P / S ; P / Z)$ \\
\hline 7. & Groups of interrelated indicators characterizing resource efficiency $(P / Z)$ \\
\hline 8. & $\begin{array}{l}\text { Indicators used in the implementation of resource and potential approaches to analysis: } E=\phi(T-I) \text {, criterion: } \\
E \rightarrow \min \end{array}$ \\
\hline
\end{tabular}

The calculation of these indicators is acceptable, as a rule, to estimate the functioning of the existing organizational structure. Carrying out their calculation in the absence of actual data, for a future perspective, calls for methods of forecasting and modeling.

One of the effective models of industrial management for knowledge-intensive enterprises is the network model, which implies the existence of a structure of enterprises, consisting of separate units, united within a common value chain. The evaluation of effectiveness of network industrial management of high-technology enterprises is a complex scientific task, which has not been resolved to date. The analysis of the toolkit for estimating the effectiveness of industrial management of high-technology enterprises was carried out in the works by Batkovskiy and Kalachanov (2015), Radu (2018), Morrissey et al. (2018), Silva and Borsato (2017), Sparrow and Cooper (2014). The particularity of this toolkit in high-technology industries has been studied in the works by Ganjeizadeh et al. (2017), McNamara (2018), Efimova (2015), Vonortas \& Zirulia (2015).

Summarizing the results of these authors' studies, it should be noted that many issues of the problem have not yet received the proper theoretical interpretation and need further research. First of all, a systematic analysis of the specifics of the evaluation of the efficiency of industrial management in high-technology industries is needed.

\section{Materials and Methods}

\subsection{Generalizing indicators of production and sales of high-technology products}

The calculation of generalized indicators of production of high-technology products is a necessary component in estimating the effectiveness of the industrial management. When calculating production volumes, a system of particular and generalized indicators should be used, since particular indicators are set for each individual type of product and are developed using all three types of meters, and generalizing indicators characterize the total volume of production and, because of a wide variety of manufactured products, are developed in the value or labor measurement. Generalizing indicators include indicators of production $P_{T}$, work-in-progress inventory $P_{n}$, gross production $P_{v}$, net products (normative) $P_{h}$, unsold $P_{n p}$ and sold products $P_{p}$. Since the total volume of hightechnology products should be determined in the cost and labor measurement, therefore, the volume of hightechnology products in the cost measurement is calculated by the formula (1): 


$$
P_{T}=\sum_{i=1}^{n} N_{i} Z_{0 i}+\sum_{j=1}^{m} P_{T j},
$$

where $n$ - the number of types of products planned for issue in physical terms; $N_{i}$ - program of the $i$-th type of products planned for issue; $Z_{0 i}$ - the wholesale price of a unit of the $i$-th type of products; $m$ - the number of types of work and services planned in monetary terms; $P_{T j}$ - the amount of production of services and services of the $j$-th type, planned in monetary terms.

The volume of knowledge-intensive products in the labor measure is determined by the formula (2):

$$
P_{T}=\sum_{i=1}^{n} N_{i} t_{c i}+\sum_{j=1}^{m} P_{T j}
$$

where $t_{c i}$ - fixed labor intensity of a unit of the $i$-th type of products; $m$ - the number of types of work and services planned in labor terms; $P_{T j}$-volume of production and services of the $j$-th type, planned in labor terms.

The amount of work in progress is calculated at the beginning and at the end of target periods by types of products. The planned volume of the work in progress will be determined with ensuring the rhythmic work of the enterprise from the first days of the period following the planned one according to the following formula (3):

$$
P_{N}=N_{s u t} T_{z},
$$

where $N_{\text {sut }}$ - average daily output in the period following the planned one; $T_{z}$ - the standard duration of the production cycle of manufacturing products in days in the period following the planned one.

The planned volume of the work in process should ensure the production of products within time equal to the duration of the production cycle. In order to obtain a general indicator of the amount of work in progress, it is necessary to determine the value $P_{N}$ by types of knowledge-intensive products in value and labor measurement. The volume of unfinished production $P_{N}$ in the value measurement by kinds of knowledge-intensive products will be determined by the formula (4):

$$
P_{N}=N_{s u t} T_{z} C_{p r} K_{n z},
$$

where $C_{p r}$ - the production cost of a unit of a product in the period preceding the planned one, $K_{n z}$ is a coefficient that takes into account the increase in costs.

Since the cost growth ratio is the ratio of the actual cost of work in progress to its value at the end of manufacturing and characterizes the average cost of products in the work in process, it is proposed to use two methods of determining $K_{n z}$ - the accurate method based on the actual distribution of work in process for operations or stages of the production process and the enlarged one. With the enlarged method of calculation, the process of increasing the costs invested in work in progress can be presented graphically under certain assumptions simplifying its calculation. As the production passes through the manufacturing process for the operations and stages of the production process, the cost of this product is gradually increasing. Therefore, in order to correctly determine the amount of work in progress in the cost measurement, one needs to know the nature of the increase in costs for production. The increase in costs can be uniform, directly proportional to the time of production (cycle time) or uneven. The nature of the increase in costs depends on the ratio of the elements of costs for manufacturing products and the structure of the manufacturing cycle and is of great importance, since it determines the amount of binding of circulating assets in work in process, i.e. the speed of their turnover. The 
measure of the binding of working capital is the production of costs for the time they are in circulation. When determining $K_{n z}$ by the enlarged (graphical) method, it can be assumed that the process of increasing costs will occur directly in proportion to the production cycle $\left(T_{P}\right)$.

Next, let us consider two cases of having the cost of manufacturing high-technology products: there are no initial expenses; there are some initial expenses. When there are no initial expenses, $K_{n z}$ is determined by the graphical chart shown in Figure 1.

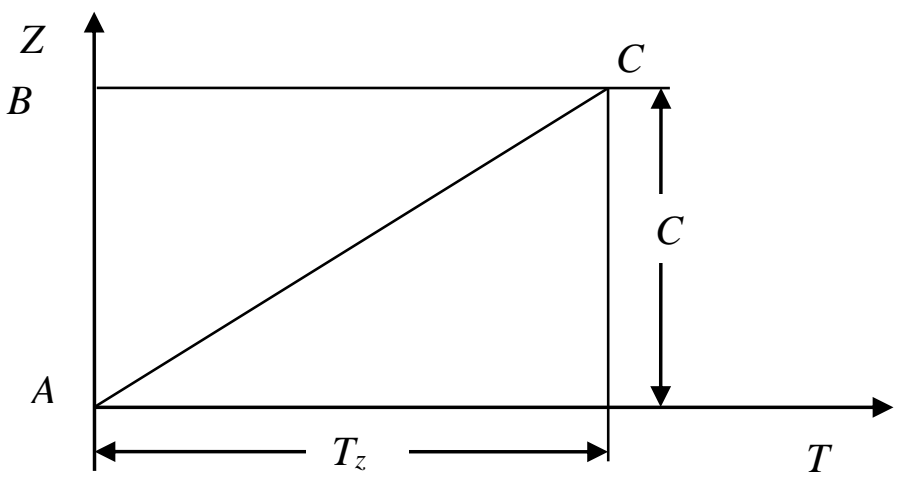

Fig. 1. The graphical chart of absence of initial expenses for production of high-technology products Source: compiled by the authors.

The graph shows that the abscissa is the manufacturing time of the product $(\mathrm{T})$, and the ordinate is the cost of manufacturing $(\mathrm{Z})$. The investment of funds in work-in-process corresponds to the area of the triangle ACD $\left(1 / 2 C_{p r} T_{z}\right)$. The cost of products in unfinished production corresponds to the area of the rectangle ABCD at the end of production $\left(C_{p r} T_{z}\right)$.

Thus, the value $K_{n z}$ will be determined by the ratio of the area of the triangle ACD to the area of the rectangle $\mathrm{ABCD}(5)$ :

$$
K_{n z}=\frac{1 / 2 C_{p r} T_{z}}{C_{p r} T_{z}}=0.5 .
$$

When the initial expenses correspond to the material expenses $\left(Z_{M}\right)$ fully invested in high-technology production at the time of its commencement, and the remaining costs increase, $K_{z}$ is determined by the graphical chart shown in Figure 2. 


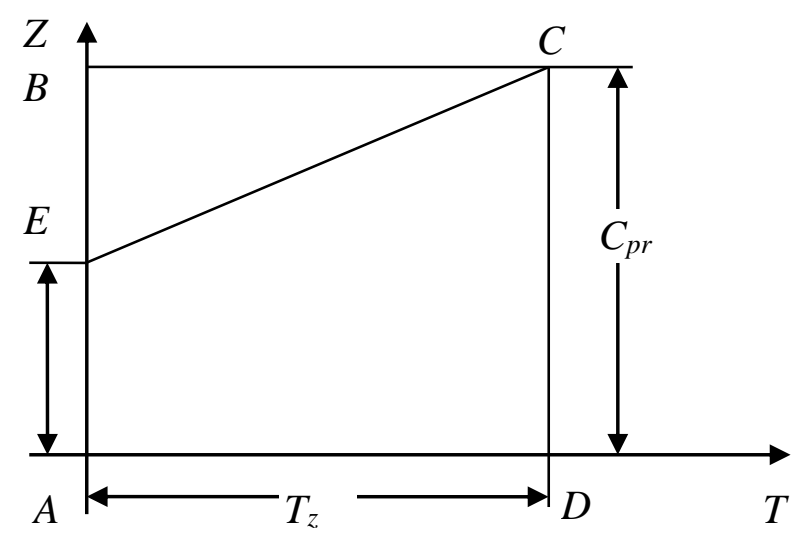

Fig. 2. The graphical chart of availability of initial expenses for production of high-technology products Source: compiled by the authors.

It can be seen that the investment of funds in work-in-process corresponds to the area of the rectangular trapezoid $\operatorname{AECD}(6)$.

$$
K_{n z}=\frac{Z_{M} T_{z}+1 / 2 T_{z}\left(C_{p r}-Z_{M}\right)}{C_{p r} T_{z}} .
$$

Applying the ratio of initial expenses to total expenses $C_{p r}$, the formula (6) is transformed through $K=\frac{Z_{M}}{C_{p r}}$ and takes the following form (7):

$$
K_{n z}=0.5(K+1)
$$

where $K_{n z}$ takes any values from 0.5 to 1.

The volume of unfinished production in the labor measurement by types of products is proposed to be determined similarly to its calculation in value terms using the formula (8):

$$
P_{N}=N_{\text {sut }} T_{z} t_{i z d} K_{T G}
$$

where $t_{i z d}$ - labor intensity of manufacturing the product in standard hours; $K_{T G}$ - the coefficient of technical readiness as the ratio of the actual labor input of the work in process to its labor input at the end of manufacturing and characterizing the average labor intensity of products in incomplete production.

The calculation procedure for $K_{T G}$ is similar to the calculation of $K_{n z}$. The total amount of work in progress in value and labor terms is determined by summing up the individual indicators for the entire range of products. The volume of gross output is good to define in cost and labor measurements by the formula (9):

$$
P_{v}=P_{T} \pm \Delta P_{N}
$$

where $P_{T}$ - the planned volume of commodity output in the respective meters, $\Delta P_{N}-$ a change of the balances of work in progress (10),

$$
\Delta P_{N}=P_{n k}-P_{n n}
$$


where $P_{n k}$ - the amount of work in progress at the end of target period; $P_{n n}$ - the amount of work in progress at the beginning of target period (determined by inventory).

To ensure the normal course of production, it is necessary to determine a rational ratio in the change in the amount of work in progress $P_{n k}$ and $P_{n n}$. Depending on the ratio $P_{n k}$ and $P_{n n}$ there could be the following version of the relationship between $P_{v}$ and $P_{T}$ :

1) $P_{v}=P_{T}$, this means that $\Delta P_{n}=0$, i.e. $P_{n k}=P_{n n}$

This option is typical for the steady production of knowledge-intensive products, when the volumes of production in the previous and subsequent periods are equal to each other.

2) $P_{v}>P_{T}$, this means that $\Delta P_{n}>0$, i.e. $P_{n k}>P_{n n}$.

This option is typical for developing high-technology production, when the volume of production increases in the subsequent period;

3) $P_{v}<P_{T}$, this means that $\Delta P_{n}<0$, i.e. $P_{n k}<P_{n n}$.

This option is typical for production curtailment when the products are removed from high-technology production in the subsequent period, and the incomplete production is converted into finished products.

The volume of gross output of high-technology enterprises should also include changes in the balances of outstanding expenses for special equipment (11):

$$
\Delta R_{c o}=R_{c o p}-R_{\text {copg }},
$$

where $R_{\text {cop }}$ - expenses for the manufacturing of special equipment in the target period; $R_{\text {copg }}$ - the amount of paid back costs for the production of special equipment in the target period.

Thus, the volume of gross output of high-technology enterprises is determined by the formula (12):

$$
P_{v}=P_{T} \pm \Delta P_{n} \pm \Delta R_{c o p}
$$

The volume of net output in accordance with the above calculations will be determined by the standards of net production (NCP). Net output calculated by $N C P$ is called standard net output. The standard net output is a part of the check price of the product including wages and deductions for social insurance to profit. The standard net output $(N C P)$ for a specific knowledge-intensive product will be determined by the formula (13):

$$
N C P=Z_{n p}+Z_{n p} K_{z}+P_{p n},
$$

where $Z_{n p}$ - basic and additional wages for manual workers with deductions for social insurance in the planned calculation of cost of the product; $K_{z}$ - the coefficient of the ratio of wages of the industrial and production personnel of the enterprise for the maintenance and management of production to the wages of production work, $P_{p n}$ - the profit on the basis of standard profitability is $K_{z}$ calculated according to the basic data of the preceding year by the formula (14):

$$
K_{z}=\frac{Z_{n n n}-Z_{n p}}{Z_{n p}},
$$


where $Z_{n n n}$ - basic and additional wages of industrial and production personnel; $Z_{n p}$ - basic and additional wages of manual workers.

Let us calculate the profit $P_{p n}$ according to the profitability standards approved in relation to the cost price less direct expenses by the formula (15):

$$
P_{p n}=0.01 R_{n} C,
$$

where $R_{n}$ is the standard profitability; $\mathrm{C}$ - cost-per-unit less expenses.

Further, the volume of standard net output is calculated on the basis of the components of gross output by summing the volume of commodity output expressed in the standard net output, and the volume of standard net output in changing the balances of the work in process. If knowledge-intensive products are planned in physical terms, then the volume of standard net output is equal to (16):

$$
P_{c}^{\prime}=\sum_{i=1}^{n} N C P_{i} N_{i},
$$

where $n$ is the number of types of high-technology products planned for issue in physical terms; $N C P_{i}-$ the standard net production of the $i$-th type of product; $N_{i}$ - a program of the $i$-th type of high-technology products planned for issue.

If the production is planned in value terms, then the volume of standard net production $P_{c}$ is determined by the formula (17):

$$
P_{c}^{\prime \prime}=\sum_{j=1}^{m} P_{T j} K_{N C P j}
$$

where $m$ - the number of types of products planned for issue in value terms; $P_{T j}$ - the volume of commercial output of the $j$-th type, planned for issue in value terms (in wholesale prices), $K_{N C P j}$ - the norm coefficient of net products of the $j$-th type. The norm coefficients of net output can be calculated according to the formula (18):

$$
K_{N C P}=\frac{P_{c}}{P_{T}},
$$

where $P_{c}$ - the volume of standard net products; $P_{T}$ - the cost of the same amount of knowledge-intensive products in wholesale prices of a high-technology enterprise ( $P_{c}$ and $P_{T}$ according to the data of two years preceding the target year).

The volume of standard net products for work in process is (19):

$$
P_{c n}=\Delta P_{n} K_{N C P}
$$

where $\Delta P_{n}$ is the change in the balances of work in progress; $K_{N C P}$ - the norm coefficient of net output (defined as the ratio of the volume of standard net output for all products with a long production cycle (over two months) to the corresponding volume of marketable output). 
The total volume of standard net output is obtained by summing all the results obtained (20), (21):

$$
\begin{aligned}
& P_{c}=P_{c}^{\prime}+P_{c}^{\prime \prime}+\Delta P_{n} K_{N C P} \\
& \quad \text { or } \\
& P_{c}=\sum_{i=1}^{n} N C P_{i} N_{i}+\sum_{j=1}^{m} P_{T j} K_{N C P} \pm \Delta P_{n} K_{N C P} .
\end{aligned}
$$

The volume of unsold output should be calculated as of the end and beginning of the target year, and the rest of unsold output at the end of the current year is the stock of unsold output at the beginning of the target year when calculations are conducted by types of knowledge-intensive products. When calculating the target stock of unsold output at the end of the planned period, it is necessary to summarize the stock of the finished knowledge-intensive output in the warehouse and the finished output shipped to the consumer taking into account that payment in the target period will not be made. Then the planned stock is (22):

$$
P_{n p k}=\left(T_{k l}+T_{o k}\right) N_{s u t} Z_{d o},
$$

where $T_{k l}$ - the standard stock of finished output in the warehouse for preparing it for shipment, in days; $T_{o k}-$ the standard term of document flow for shipped products, in days; $N_{s u t}$ - average daily output in the period following the target one (it is necessary to take a five-year plan of a high-technology enterprise); $Z_{d o}$ current wholesale price.

Then the volume of sold products can be calculated (23):

$$
P_{p}=P_{T}+P_{n p n}-P_{n p k},
$$

where $P_{n p n}$ - the volume of unsold knowledge-intensive products as of the beginning of the target period.

\subsection{Evaluation of the integration of production capacity}

\begin{tabular}{|c|c|c|c|}
\hline Principles & Indicator & $\begin{array}{c}\text { The calculating } \\
\text { formula }\end{array}$ & Name \\
\hline Updating & $\begin{array}{l}K_{a F}, K_{a N}, K_{a C}-\text { updating } \\
\text { coefficient (functions, elements, and } \\
\text { links) }\end{array}$ & $\begin{array}{l}K_{a F}=F_{n} / F_{o b} \\
K_{a N}=N_{n} / N_{o b} \\
K_{a C}=C_{n} / C_{o b}\end{array}$ & $\begin{array}{l}F_{n}-\text { necessary functions; } \\
N_{n}-\text { the number of useful elements; } C_{n}-\text { the } \\
\text { number of useful links; } \\
F_{o b}, N_{o b}, C_{o b}-\text { the total number of functions, } \\
\text { elements and links in the system. }\end{array}$ \\
\hline Concentration & $\begin{array}{l}K_{b F}, K_{b N}, K_{b C}-\text { the coefficient } \\
\text { of functionality level (concentration }\end{array}$ & $\begin{array}{l}K_{b F}=F_{o c n} / F_{o b} \\
K_{b N}=N_{o c n} / N_{o b}\end{array}$ & $\begin{array}{l}F_{o c n}-\text { the number of basic functions; } N_{o c n}- \\
\text { the number of carriers of basic }\end{array}$ \\
\hline
\end{tabular}

Using a set of indicators of the functional structure of the production system of the enterprise (see Table 2), which is based on the formalization of the main characteristics and relationships of the organizational structure, its integral evaluation can be calculated.

Table 2. The proposed indicators of the functional structure of the production system of the enterprise 
The International Journal

ENTREPRENEURSHIP AND SUSTAINABILITY ISSUES

ISSN 2345-0282 (online) http://jssidoi.org/jesi/ 2018 Volume 6 Number 2 (December) http://doi.org/10.9770/jesi.2018.6.2(8)

\begin{tabular}{|c|c|c|c|}
\hline Principles & Indicator & $\begin{array}{c}\text { The calculating } \\
\text { formula }\end{array}$ & Name \\
\hline & functions, elements and links) & $K_{b C}=C_{v s} / C_{v n}$ & $\begin{array}{l}\text { functions; } C_{v s}, C_{v n}-\text { the number of external } \\
\text { and internal links. }\end{array}$ \\
\hline Compatibility & $\begin{array}{l}K_{c F}, K_{c N}, K_{c C}-\text { compatibility } \\
\text { coefficient (functions, elements, and } \\
\text { links) }\end{array}$ & $\begin{array}{l}K_{c F}=1-F_{\kappa} / F_{o b} \\
K_{c N}=1-N_{\kappa} / N_{o b} \\
K_{c C}=1-C_{\kappa} / C_{o b}\end{array}$ & $\begin{array}{l}F_{\kappa}-\text { coordination functions; } \\
N_{\kappa}, C_{\kappa}-\text { respectively, the number of } \\
\text { intermediary elements that perform the } \\
\text { coordination function. }\end{array}$ \\
\hline Flexibility & $\begin{array}{l}K_{f s}-\text { the coefficient of functional } \\
\text { potential; } K_{c s}-\text { the coefficient of } \\
\text { the potential of links }\end{array}$ & $K_{f s}=F_{p} /\left(F_{p}+F_{o b}\right)$ & $\begin{array}{l}F_{p}-\text { the number of potential functions; } \\
C_{p}-\text { the number of possible links; }\end{array}$ \\
\hline
\end{tabular}

Source: compiled by the authors.

The use of these indicators allows giving a preliminary conclusion. The value of the indicator that determines their organizational potential reflects only the formal side of the interaction of the integrated enterprises. The formation and justification of the initial data for preparation of management decisions concerning the implementation of innovative measures are determined by the state of the segments of the domestic and foreign markets for the respective products. A methodology for calculating the integration of the industrial and production capacity of an enterprise can be developed on this basis.

\subsection{Estimations of the accumulated potential of high-technology enterprises}

To carry out all the strategic planning activities of business processes in a high-technology enterprise, there should be an indicator "accumulated potential" of an enterprise $X(\alpha, t)$, which depends on the time $t$ of some flow $x(t)$, as a function defined by the expression (24):

$$
X(\alpha, t)=\sum_{i} \frac{x\left(t-\tau_{i}\right)}{(1+\alpha)^{i}},
$$

where $\alpha$ - the level of specific profitability of production in the relevant market segment, $\% ; x\left(t-\tau_{i}\right)-$ the volume of income received from the sale of manufactured products for the target period $\left(t-\tau_{i}\right)$ in the currency of the country of origin.

The indicator "accumulated potential" $X(\alpha, t)$ reflects the result of the company's incomes and payments of previous years. The increase (from $U$ to "input" to $X$ "output") in the index "accumulated potential" $X(\alpha, t)$ can show robustness against competiveness of the company. Next, the ratio of the output potential $U$ to the input potential $X$ is calculated. It makes it possible to estimate the accumulated potential during the target period. At the same time, it is possible to justify the increase or decrease in the obtained integrated characteristic of the company's competitiveness (formula 25):

$$
\mathrm{k}_{\mathrm{rc}}=\frac{\mathrm{X}}{\mathrm{U}} \text {. }
$$


The International Journal

ENTREPRENEURSHIP AND SUSTAINABILITY ISSUES

ISSN 2345-0282 (online) http://jssidoi.org/jesi/ 2018 Volume 6 Number 2 (December) http://doi.org/10.9770/jesi.2018.6.2(8)

In the process of determining the groups of parameters of the enterprise's competitiveness, the main indicator is $\beta$. Its value can be determined from the formula 25 and compared with the result obtained $k_{\kappa c}$. The area of unsustainable development of a high-technology enterprise establishes an increase in the capacity at the input, and the production capacity of the enterprise is reduced as a result of inefficient use of resources. In this situation, the value should meet this condition: $k_{K C}<\beta$. The increase in the output potential $X$ over the input potential $U$ can be due to an increase in the production potential and a change in the input flow to the subsequent result. This condition is met when the activity area of a competitive high-technology enterprise $k_{K C}>\beta+\Delta \beta$. If the condition $X>U$ is met, the condition $\beta<k_{K C}<\beta+\Delta \beta$ shows that the margin of competitiveness is reduced. Thus, the point $k_{K C}$ is closer to the coordinates $X, U$ and the probability of crossing the boundaries increases. The value of intervals $[\beta, \beta+\Delta \beta]$ can be used to combine high-technology enterprises with the aim of increasing the competitiveness of knowledge-intensive products.

The deviations from positive maximum values of the coefficient $k_{K C}$ from $\beta$ or creation of conditions $k_{K C}$ within the scope of the allowed values are the key task in the production management and industrial enterprise. It should be noted that any organizational decision should be ensured by exceeding $X$ by $U$, and when estimating the forecast advantages of the competitiveness of enterprises, it is necessary to take into account the length of the time interval and the reserve of production capacity.

\section{Results and Discussion}

Estimation of the effectiveness of high-technology enterprises competitiveness.

Formulation of the task. Let us suppose a company "A" has a gain of 50 billion USD, the balance is 150 billion USD, the company "B" has a gain of 15 billion USD, the balance is 150 billion US dollars. It is necessary to calculate the efficiency of the potential of enterprises taking into account their integration.

The solution of the task. The average values of the competitiveness coefficients $k_{K C}$ for enterprises " $\mathrm{A}$ " and " $\mathrm{B}$ " over the period of 4 years are equal to 0.28 and 0.08 , respectively. The comparison of these indicators allows stating that the competitiveness of the second enterprise is 3.5 times lower than the former has. The analysis of the trends of the calculated values $k_{K C}$ (Table 3) indicates their growing difference among companies and a significant drop in the competitiveness of a company " $\mathrm{B}$ " in 4 years.

Table 3. The values of $k_{K C}$ enterprise competitiveness index

\begin{tabular}{lccrr}
\hline \multicolumn{1}{c}{ Company's name } & 1 year & 2 year & 3 year & 4 year \\
\hline Enterprise A & 0.7 & 0.2 & 0.1 & 0.2 \\
Enterprise B & 0.2 & 0.1 & 0.0 & -0.1 \\
\hline \multicolumn{5}{c}{ Source: compiled by the authors. }
\end{tabular}

The negative value of $k_{K C}(-0.1)$ shows inefficiency in the use of the assets of the enterprise - with an increase in 4 years in both non-current (by 30\%) and working assets (by 6\%): the growth of the accumulated potential of assets is accompanied by a decrease in the value of the accumulated potential of proceeds from the sale of products. The alliance of enterprises " $\mathrm{A}$ " and "B" while restructuring the production system when integrating 
leads to an average value of the competitiveness index at the level of 0.18 . The initial decline in the competitiveness index $k_{K C}$ to zero is replaced by an increase in this value, which characterizes the manifestation of positive changes caused by restructuring (Table 4).

Table 4. The values of the index of competitiveness $k_{K C}$ in the integration of enterprises

\begin{tabular}{|c|c|c|c|c|}
\hline Company's name & 1 year & 2 year & 3 year & 4 year \\
\hline Company A + Company B & 0.5 & 0.2 & 0.0 & 0.1 \\
\hline
\end{tabular}

If these structural changes in the production system of two enterprises remain, achieving the competitiveness of company "A" $\left(k_{K C}=0.7\right)$ should help to reduce this long period of increasing the competitiveness of the new integration of enterprises.

\section{Conclusions}

The realization of structural changes in high-technology industries requires an estimation of the effectiveness of taken decisions. The way of determining the economic feasibility of organizational solutions is focused on fixing the dynamics of competitiveness of the transformed object. The proposed criterion for estimating the competitiveness of a high-technology enterprise is based on the correlation of its potentials over a certain time interval taking into account actual risks. The establishment of the boundary values of the indicator $k_{K C}$ makes it possible to segment the competitiveness space and identify areas of different resource consumption efficiency. It can be seen that there is a lag in one of the indicator of average competitiveness of the compared enterprises; the analysis of the dynamics $k_{K C}$ determines not only the progressive or regressive nature of the trend but also provides an opportunity to reasonably choose the production site as the core component of the subsequent integration of producers.

\section{Aknowledgements}

The study was supported by the Russian Foundation for Basic Research (RFBR), project No. 16-06-00028.

\section{References}

Batkovskiy, A.M.; \& Kalachanov, V.D. 2015. Modeling of innovative development of economic systems, Issues of Radio Electronics 2: 258-279.

Batkovskiy, A.M.; Fomina, A.V.; Batkovskiy, M.A.; Klochkov, V.V.; \& Semenova, E.G. 2016. Implementation risks in investment projects on boosting high-tech business production capacity: analysis and management, Journal of Applied Economic Sciences 6(44): 12001209.

Berger, R. 2014. Industry 4.0. The New Industrial Revolution, Roland Berger Strategy Consultants.

Chen, J.K.C.; Sun, B.S.S.; \& Batchuluun, A. 2016. Exploring the influence factors for creation one Knowledge hub of Science Park: Comparison between Silicon Valley and Hsinchu Science Park, In: Portland International Conference on Management of Engineering and Technology: Technology Management for Social Innovation, 4-8 Sept. 2016, IEEE, 1156-1171, https://doi.org/10.1109/PICMET.2016.7806788. 
De Sousa Damiani, J.H. 2016. Regional development in Brazil and the challenges facing technology-intensive cities: A proposal for a framework of a municipal innovation system, In: Portland International Conference on Management of Engineering and Technology: Technology Management for Social Innovation, 4-8 Sept. 2016, IEEE, 510-522, https://doi.org/10.1109/PICMET.2016.7806558.

Efimova, N.S. 2015. Formation of methods of information support of processes of development of science-intensive products in the conditions of information security of the enterprise, Bulletin of the Moscow Aviation Institute 2: 214-220.

Ganjeizadeh, F.; Lei, H.; Goraya, P.; \& Olivar, E. 2017. Organizational performance and indicators: trends and opportunities, In: Pellicciari, M., Peruzzini, M. (eds.), 27th International Conference on Flexible Automation and Intelligent Manufacturing Modena, Italy, Part 1 of 3, 27-30 June 2017 (FAIM 2017), 1925-1933.

Hong, X.; Zhao, D.; \& Wang, Z. 2016. Managing technology licensing for stochastic R\&D: from the perspective of an enterprise information system, Enterprise Information Systems 10(8): 845-862, https://doi.org/10.1080/17517575.2015.1021855.

Huys, R.; Ramioul, M.; \& Van Hootegem, G. 2013. High Performance Workplaces: Background Paper for the Third European Company Survey, European Foundation for the Improvement of Living and Working Conditions, Dublin.

Ingvaldsen, J.A. 2015. Organizational Learning: Bringing the Forces of Production Back in, Organization Studies Forthcoming 36(4): 423444, https://doi.org/10.1177/0170840614561567.

Knutstad, G.J.; \& Ravn, E. 2014. Technology utilization as competitive advantage - a sociotechnical approach to high performance work systems, Advanced Materials Research, 1039: 555-561, https://doi.org/10.4028/www.scientific.net/AMR.1039.55.

Lee, B.H. 2011. The political economics of industrial development in the Korean automotive sector, International Journal of Automotive Technology and Management 11(2): 137-151, https://doi.org/10.1504/IJATM.2011.039541.

Li, C.; Bai, Y.; Xiang, X.; \& Xie, X. 2017. To mine coordinated development degrees of high-tech equipment manufacturing industry and logistics industry via an improved grey hierarchy analysis model, Journal of Grey System 29(1): 105-119.

Lyu, J.; Wang, W.; Ren, Y.; Feng, W.; \& Zhao, J. 2016. An evaluation method for use phase affordability of aviation equipment, In: International Conference on System Reliability and Science, 15-18 Nov. 2016, 42-45, https://doi.org/10.1109/ICSRS.2016.7815835.

Manturov D.V.; \& Efimova, N.S. 2012. The introduction of information systems for science-intensive products for the organization of production in the aircraft industry, Armament and Economics 3(19): 50-55.

McNamara, C. 2018. Organizational Performance management - evaluating and improving organizations, from http://managementhelp.org/organizationalperformance/index.html, accessed February 11, 2018.

Morrissey, R.; Guarraia, P.; Pauwels, V.; \& Sampathkuma, S. 2018. Building efficient organizations, fromhttp://www.bain.com/publications/articles/building-efficient-organizations.aspx, accessed February 11, 2018.

Narkunienè, J.; Ulbinaite, A. 2018. Comparative analysis of company performance evaluation methods, Entrepreneurship and Sustainability Issues 6(1): 125-138. https://doi.org/10.9770/jesi.2018.6.1(10)

Panahifar, F.; Byrne, P.J.; \& Heavey, C. 2014. ISM analysis of CPFR implementation barriers, International Journal of Production Research 52(18): 5255-5272, https://doi.org/10.1080/00207543.2014.886789

Pokrajac, S.; Nikolić, M.; \& Filipović, M. 2016. Industrial competitiveness as a basis of Serbian reindustrialization, Journal of Applied Engineering Science 14(2): 248-259, https://doi.org/10.5937/jaes14-10442

Radu, C. 2018. Modern instruments for measuring organizational performance, from http://www.academia.edu/1628842/Modern_Instruments_For_Measuring_Organizational_Performance, accessed February 11, 2018.

Rolfsen, M.; \& Langeland, C. 2012. Successful maintenance practice through team autonomy, Employee Relations 34(3): 306-321, https://doi.org/10.1108/01425451211217725

Silva, F.A.D.; \& Borsato, M. 2017. Organizational performance and indicators: Trends and Opportunities Federal University of Technology, Procedia Manufacturing 11: 1925-1932, https://doi.org/10.1016/j.promfg.2017.07.336 
The International Journal

ENTREPRENEURSHIP AND SUSTAINABILITY ISSUES

ISSN 2345-0282 (online) http://jssidoi.org/jesi/

2018 Volume 6 Number 2 (December)

http://doi.org/10.9770/jesi.2018.6.2(8)

Sparrow, P.; \& Cooper, C. 2014. Organizational effectiveness, people and performance: new challenges, new research agendas, Journal of Organizational Effectiveness: People and Performance (Lancaster University) 1(1): 2-13, https://doi.org/10.1108/JOEPP-01-2014-0004

Vonortas, N.; \& Zirulia, L. 2015. Strategic technology alliances and networks, Economics of Innovation and New Technology 24(5): 490509, https://doi.org/10.1080/10438599.2014.988517

Aleksandr M. BATKOVSKIY, Dr. Sci. (Economics), Senior Researcher, JSC “Central Research Institute of Economy, Management and Information Systems "Electronics", Moscow, Russian Federation. Research interests: economics of industry, management, production efficiency, sustainable systems.

ORCID ID: orcid.org/0000-0002-5145-5748

Natalya S. EFIMOVA, Cand.Sci. (Economics), Assistant professor of the Department of a control system of economic objects, Moscow aviation institute (national research university), Moscow, Russian Federation. Research interests: economic problems of the organization of aircraft manufacturing production, assessment of effective management of the hi-tech enterprises, problems of industrial and technological character.

ORCID ID: orcid.org/0000-0002-2779-4758

Vyacheslav D. KALACHANOV, Dr. Sci. (Economics), Professor of the Department of a control system of economic objects, Moscow aviation institute (national research university), Moscow, Russian Federation. Research interests: economic problems of the organization of aircraft manufacturing production, assessment of effective management of the hi-tech enterprises, problems of industrial and technological character.

ORCID ID: orcid.org/0000-0001-6829-4189

Elena G. SEMENOVA, Dr. Sci. (Engineering), Professor, Director of the Institute of Innovation and master basic training, SaintPetersburg State University of Aerospace Instrumentation, St. Petersburg, Russian Federation. Research interests: innovative activity, modeling, sustainable systems, management, applied mathematics.

ORCID ID: orcid.org/0000-0001-8312-4903

Alena V. FOMINA, Dr. Sci. (Economics), Assistant professor, JSC “Central Research Institute of Economy Management and Information Systems "Electronics", Moscow, Russian Federation. Research interests: regional economy, industrial economy, development strategies and restructuring, strategic planning, high-tech production structures, industry analysis, financial and economic planning, sustainable economic systems.

ORCID ID: orcid.org/0000-0002-5853-0309

Viktor M. BALASHOV, Dr. Sci. (Engineering), Professor, JSC «Scientific and Production Enterpise "Radar MMS"», Saint-Petersburg, Russian Federation. Research interests: reengineering, enterprise economics, economic and mathematical modeling.

ORCID ID: orcid.org/0000-0003-4642-5701

Register for an ORCID ID:

https://orcid.org/register

Copyright (C) 2018 by author(s) and VsI Entrepreneurship and Sustainability Center

This work is licensed under the Creative Commons Attribution International License (CC BY).

http://creativecommons.org/licenses/by/4.0/

cC) (i) Open Access 